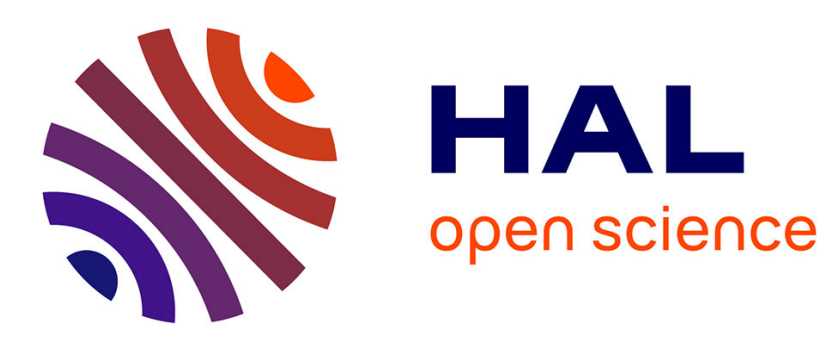

\title{
Influence of flooding on the degradation of linuron, isoproturon and metolachlor in soil
}

\author{
Cesare Accinelli, Claudio Screpanti, Alberto Vicari
}

\section{To cite this version:}

Cesare Accinelli, Claudio Screpanti, Alberto Vicari. Influence of flooding on the degradation of linuron, isoproturon and metolachlor in soil. Agronomy for Sustainable Development, 2005, 25 (3), pp.401-406. hal-00886303

\section{HAL Id: hal-00886303 https://hal.science/hal-00886303}

Submitted on 1 Jan 2005

HAL is a multi-disciplinary open access archive for the deposit and dissemination of scientific research documents, whether they are published or not. The documents may come from teaching and research institutions in France or abroad, or from public or private research centers.
L'archive ouverte pluridisciplinaire HAL, est destinée au dépôt et à la diffusion de documents scientifiques de niveau recherche, publiés ou non, émanant des établissements d'enseignement et de recherche français ou étrangers, des laboratoires publics ou privés. 


\title{
Influence of flooding on the degradation of linuron, isoproturon and metolachlor in soil
}

\author{
Cesare ACCINELli*, Claudio SCREPANTI, Alberto VICARI \\ Department of Agro-Environmental Science and Technology, University of Bologna, Viale Fanin 44, 40127 Bologna, Italy
}

(Accepted 4 May 2005)

\begin{abstract}
Degradation of pesticides in soil usually refers to normally aerated conditions. However, considering that under some circumstances, fields treated with pesticide can be subject to flooding phenomena, more information on pesticide persistence under these conditions is needed. The main objective of the present study was to investigate the persistence of linuron, isoproturon and metolachlor in soil samples incubated under flooding conditions. During the whole incubation period, changes in soil Eh, $\mathrm{pH}$ and microbial $\mathrm{C}$ were measured. Flooding conditions produced different effects on the persistence of the three herbicides. More specifically, flooding conditions led to a significant increase in linuron and isoproturon persistence. The half-lives of linuron and isoproturon in flooded soil were 1.8 and 1.4 times higher than in nonflooded soil, respectively. An opposite phenomenon was observed with metolachlor. The half-life of metolachlor was reduced from 32.2 to 24.1 days in nonflooded and flooded soil, respectively. Soil Eh rapidly decreased in soil samples incubated under flooding conditions, passing form $368.0 \mathrm{mV}$ to $-225.5 \mathrm{mV}$ within the first week of flooding. No significant changes in soil microbial C in soil samples incubated under the two water regimes were observed. The results obtained from the present experiment showed that information from normally aerated soil conditions is not correctly applicable to predict herbicide persistence under flooding conditions.
\end{abstract}

herbicide persistence / linuron / isoproturon / metolachlor / flooding conditions

\section{INTRODUCTION}

The southeastern Po Valley (Italy) largely consists of lowlying and flood-prone areas with topography levels ranging from 0 to $-5 \mathrm{~m}$ of the sea level. However, a modern poldertype water management allows the extensive and profitable cultivation of these low-lying lands. The frequent occurrence of heavy rains, in autumn and spring, can lead to the establishment of temporary or prolonged flooding conditions in cultivated fields. In some cases, prolonged flooding phenomena can severely injure cultivated crops, forcing farmers to re-sow the same or, more frequently, different crop species.

Flooded soils undergo significant chemical changes, the most obvious being that most flooded soils convert from oxidizing to reducing conditions (McKee and Kelvin, 1993; Kelly and Wilson, 2000). The oxidation-reduction potential or redox potential (Eh) is a qualitative measure of the intensity of this change (Ponnamperuma et al., 1967). Eh values of unsaturated and sufficiently aerated soil range from +350 to $+700 \mathrm{mV}$, while in flooded soils Eh ranges from +350 to $-250 \mathrm{mV}$ (DeLaune et al., 1997). Upon flooding, oxygen is rapidly depleted in soil and disappears at an Eh value of approximately
+ $350 \mathrm{mV}$ (DeLaune et al., 1997). In such conditions, activity of facultative and strictly anaerobic microorganisms predominates within the soil microbial community (Liesack et al., 2000).

Some authors reported that the oxidation-reduction potential of soils has a significant influence on the degradation rate of certain pesticides (Wolfe et al., 1990; McFarland et al., 1996). Decrease in the degradation rate of pesticides under flooding conditions has been reported, although degradation can be significant even under strongly reducing conditions (Shapir et al., 1998; Kelly et al., 2000). In addition, flooding can significantly affect pesticide movement in soil. Some authors reported an increase in the mass of pesticides entering ditches and rivers neighboring agricultural areas (Gomme et al., 1991; Goolsby et al., 1994).

Metolachlor, linuron and isoproturon are widely used herbicides. Isoproturon and linuron are substituted urea herbicides, while metolachlor is an acetanilide herbicide. In the southeastern Po Valley, isoproturon is mainly used for pre- and post-emergence control of annual grasses and broad-leaved weeds in wheat, while linuron and metolachlor are largely employed as residual herbicides in maize and soybean production. Degradation of herbicides in soil is an important aspect

\footnotetext{
* Corresponding author: accinel@agrsci.uinbo.it
} 
to consider in the prediction of their environmental fate. Degradation of metolachlor, linuron and isoproturon in unsaturated soil has been studied by numerous authors (Walker et al., 1991; Dinelli et al., 2000; Accinelli et al., 2001; Walker et al., 2001), but little is known about their degradation in flooded soils.

The flooding phenomena occurred in 1998 and 2001 and inundated most of the low-lying agricultural areas of the southeastern Po Valley. In both years, soil remained waterlogged for a significantly long period, forcing farmers to change field crop plans. In crop planning decisions, fields treated with residual herbicides were empirically retained to present restricted cropping choices. In fact, in the absence of information regarding herbicide persistence in flooded soils, besides agronomical and economical considerations, intended crops were empirically chosen on the basis of their tolerance to pre-flooding applied herbicides. However, considering that herbicide degradation in waterlogged soil is, to some extent, supposed to occur, more detailed information concerning the effect of flooding on herbicide persistence in soil is consequently needed to rationally set up post-flooding crop and weed control programs.

The objective of the present research was to investigate the persistence of metolachlor, linuron and isoproturon in soil samples incubated under flooding conditions. In addition, during the whole incubation period, changes in soil Eh, $\mathrm{pH}$ and microbial $\mathrm{C}$ were measured.

\section{MATERIALS AND METHODS}

\subsection{Soil}

Soil samples were collected from the top $10 \mathrm{~cm}$ of a field with no previous pesticide history in Migliarino (Ferrara, Italy). The soil is representative of large areas of low-lying fields in the southeastern Po Valley, frequently subjected to flooding events. The soil was classified as a Jolanda clay loam (finesilty, mixed, mesic Sulfic Endoaquepts). Analysis of the soil revealed the following characteristics: $251 \mathrm{~g} \mathrm{~kg}^{-1}$ sand, $411 \mathrm{~g} \mathrm{~kg}^{-1}$ silt, $338 \mathrm{~g} \mathrm{~kg}^{-1}$ clay, organic $\mathrm{C}$ content $66 \mathrm{~g} \mathrm{~kg}^{-1}, \mathrm{pH}$ (1:2.5 soil/ water) of 6.3 , and a water content of $32.2 \%$ at an applied pressure of $33 \mathrm{kPa}$. Collected soil samples were accurately mixed, air-dried overnight and passed through a 2-mm sieve. A portion of the collected soil was sterilized by autoclaving two times for $1 \mathrm{~h}$ at $121{ }^{\circ} \mathrm{C}$ and $103 \mathrm{kPa}$.

\subsection{Soil incubation and herbicide treatments}

Samples of $25 \mathrm{~g}$ of soil (air-dry basis) were weighed in sterile culture tubes. Before the beginning of the experiment, moisture of nonsterile soil samples was adjusted to the field capacity $(-33 \mathrm{kPa})$ by adding distilled water and soil samples were kept in the dark in a climatic chamber at $25^{\circ} \mathrm{C}( \pm 0.5)$ for 10 days. The conditioning period of 10 days allowed the soil to establish a steady-state level of microbial activity. Conditioned nonsterile and sterile soil samples were treated with an appropriate water solution of commercial formulation of metolachlor (Dual $^{\mathrm{TM}} 960$ EC, Syngenta Ltd., Basel, Switzerland), linuron (Ureon $^{\text {TM }} 420$ WP, Scam s.r.l., Modena, Italy) and isoproturon (Arelon 500 SC, Agrevo Italia S.p.A., Milano, Italy), to provide a final concentration of $8 \mathrm{mg}$ a.i. $\mathrm{kg}^{-1}$ (air-dry basis).

Twenty-four hours after the herbicide treatment, distilled water was added to keep soil samples at the field capacity (non- flooded samples) and at $2 \mathrm{~cm}$ above the soil surface (flooded samples). In the case of autoclaved soil samples, sterile water was used. Finally, flooded and nonflooded samples were incubated in a climatic chamber in the above described conditions. The moisture level of soil samples was checked at 4-day intervals and adjusted to the imposed initial value. Incubation times were $0,5,10,15,30,40$ and 50 days after treatment. At each sampling time, triplicate samples were removed and stored at $-20{ }^{\circ} \mathrm{C}$ until extraction and analysis.

\subsection{Herbicide analyses}

Nonflooded and flooded soils were extracted by adding $15 \mathrm{~mL}$ of acetonitrile, shaking for 1 hour, centrifuging the slurry for $10 \mathrm{~min}$ at $3000 \times g$ and removing the supernatant. Supernatant from each soil extraction was filtered through a $0.2-\mu \mathrm{m}$ size filter. Herbicide analyses were carried out by high performance liquid chromatography, using a Beckman (Palo Alto, CA) System Gold 126 liquid chromatograph equipped with a $250 \times$ $4.6 \mathrm{~mm}$ Beckman Ultrasphere C18 5- $\mu \mathrm{m}$ particle size and a Beckman Model 168 dual-wavelength UV detector.

Metolachlor and linuron were analyzed following the methodology described elsewhere (Accinelli et al., 2001). Briefly, isocratic elution was carried out at room temperature and the eluent flow was set at $1 \mathrm{~mL} \mathrm{~min}^{-1}$ with an acetonitrile:water ratio of 55:45 (v/v) for metolachlor and 60:40 (v/v) for linuron. Metolachlor and linuron were detected at 222 and $210 \mathrm{~nm}$, respectively. Isoproturon analysis was performed at $240 \mathrm{~nm}$, using a mobile phase of water/acetonitrile $(50 / 50 \mathrm{v} / \mathrm{v})$ at a flow

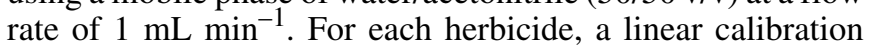
curve based on peak area was generated using known analytical grade herbicide (chemical purity $>99 \%$ ) concentrations. The extraction procedure afforded herbicide recoveries $>90 \%$. In flooded samples, herbicide concentrations were calculated considering the concentrations in soil and in the respective flooded water.

Herbicide half-lives were calculated by the slopes of the straight lines obtained by plotting the natural logarithm of the percentage of herbicide remaining against the time. The degradation half-life values were subjected to analysis of variance and significant differences $(P<0.05)$ determined by a least significant difference test.

\subsection{Eh and pH measurements}

Soil Eh was measured using a combined platinum and $\mathrm{Ag} /$ $\mathrm{AgCl}$ electrode as reference, attached to a $\mathrm{pH} / \mathrm{mV}$ meter. Electrode reliability was periodically checked by comparing the electrode potential of standard solutions of 468, 258 and $192 \mathrm{mV}$. Soil Eh measurements were made by transferring soil samples to a hermetically capped cylinder fitted with a platinum electrode and $\mathrm{N}_{2}$-gas inlet. Soil Eh was measured after the electrode, introduced $2.5 \mathrm{~cm}$ below the soil surface, had equilibrated in the soil (Wang and Bettany, 1993). According to McGeehan and Naylor (1994), the head space of each sample was purged with $\mathrm{O}_{2}$-free $\mathrm{N}_{2}$ gas during Eh measurements. Eh measurements were completed within 5 to $10 \mathrm{~min}$ per sample. The reported Eh values are a weighted average of the potentials of all the redox couples present (Bohn, 1968).

Soil $\mathrm{pH}$ was measured at a 1:2.5 soil/water ratio using a glass electrode. Eh and $\mathrm{pH}$ were measured during the whole incubation period at 5-day intervals. 
Table I. Estimated half-lives ( \pm standard error) of metolachlor, linuron and isoproturon as a function of water level regimes and soil sterilization treatment.

\begin{tabular}{|c|c|c|c|c|c|c|c|c|}
\hline \multirow[t]{3}{*}{ Herbicide } & \multicolumn{4}{|c|}{ Nonflooding } & \multicolumn{4}{|c|}{ Flooding } \\
\hline & \multicolumn{2}{|c|}{ Nonsterile } & \multicolumn{2}{|c|}{ Sterile } & \multicolumn{2}{|c|}{ Nonsterile } & \multicolumn{2}{|c|}{ Sterile } \\
\hline & $\begin{array}{c}\text { Half-life } \\
\text { (days) }\end{array}$ & $\mathrm{r}^{2 *}$ & $\begin{array}{c}\text { Half-life } \\
\text { (days) }\end{array}$ & $r^{2}$ & $\begin{array}{l}\text { Half-life } \\
\text { (days) }\end{array}$ & $r^{2}$ & $\begin{array}{c}\text { Half-life } \\
\text { (days) }\end{array}$ & $\mathrm{r}^{2}$ \\
\hline linuron & $29.1 \pm 0.30$ & 0.96 & no degr. & - & $52.4 \pm 0.4$ & 0.91 & no degr. & - \\
\hline isoproturon & $24.0 \pm 0.81$ & 0.92 & no degr. & - & $33.6 \pm 0.81$ & 0.90 & no degr. & - \\
\hline metolachlor & $32.2 \pm 1.10$ & 0.90 & no degr. & - & $24.1 \pm 0.50$ & 0.87 & no degr. & - \\
\hline
\end{tabular}

* Coefficient of determination.

The employed $\mathrm{pH} /$ Eh meter device (GLP 22), electrodes and standard solutions were provided by Crison Instruments S.A. (Alelle, Spain).

\subsection{Soil microbial biomass}

Soil microbial biomass was estimated using the fumigation extraction method (Vance et al., 1987). Sampling times were 0, 25 and 50 DAT. For the fumigation treatment, soil samples were placed in 5-L desiccators containing a 25-mL glass beaker with $25 \mathrm{~mL}$ ethanol-free chloroform. After incubation for 24 hours in the dark at $25^{\circ} \mathrm{C}$, the chloroform was removed by repeated evacuation. In order to overcome limitations in the fumigation efficiency when exposing flooded soil to choroform vapor, before the fumigation treatment, soil moisture of flooded samples was reduced to approximately the field capacity by keeping the samples in a ventilated climatic chamber for 24 hours at $30{ }^{\circ} \mathrm{C}$. Fumigated and unfumigated soil samples were extracted with $0.5 \mathrm{M} \mathrm{K}_{2} \mathrm{SO}_{4}$ for 60 min in a rotary shaker and then filtered through a glass-fiber filter (Whatman GF/A). Organic $\mathrm{C}$ in the extract was determined by dichromate digestion as reported in Vance et al. (1987). Soil microbial C $\left(\mathrm{B}_{\mathrm{c}}\right)$ was calculated by the expression $\mathrm{B}_{\mathrm{c}}=\mathrm{E}_{\mathrm{c}} / \mathrm{k}_{\mathrm{ec}}$, where $\mathrm{E}_{\mathrm{c}}=$ (organic $\mathrm{C}$ extracted from fumigated soils) minus (organic $\mathrm{C}$ extracted from unfumigated soils). A correction factor $\left(\mathrm{k}_{\mathrm{ec}}\right)$ of 2.64 was adopted (Vance et al., 1987).

A factorial design with soil treatments (sterile and nonsterile) and soil moisture regimes (flooding and nonflooding) as variables were employed. Measurement of herbicide halflives, soil $\mathrm{Eh}, \mathrm{pH}$ and microbial $\mathrm{C}$ was carried out in the above described 25-g samples. Means for half-life, soil Eh and $\mathrm{pH}$, and soil microbial $\mathrm{C}$ were determined using data from three replicates and separated by LSD at $P \leq 0.05$.

\section{RESULTS AND DISCUSSION}

\subsection{Herbicide degradation}

Degradation of linuron, isoproturon and metolachlor in both nonsterile and sterile soil, incubated under the two different moisture regimes (nonflooding and flooding), followed first- order kinetics. The coefficients of regression of natural logarithm of concentration against time ranged from 0.87 to 0.96 and were statistically significant, thus indicating that the assumption of first-order kinetics was acceptable.

Table I summarizes half-lives of the three herbicides in soil samples subjected to the studied experimental conditions. In nonsterile soil, herbicide degradation was significantly influenced by soil moisture level. Under nonflooding conditions, the estimated half-lives of linuron and isoproturon in nonsterile soil samples were 29.1 and 24.0 days, respectively. These findings are in agreement with other studies (Walker and Welch, 1992; Walker et al., 2001). Linuron and isoproturon persistence increased under flooding conditions. The half-lives of linuron and isoproturon in flooded soil were 1.8 and 1.4 times higher than in nonflooded soil, respectively. Increasing herbicide persistence as a consequence of flooding has also been reported by other authors (Chung et al., 1995; DeLaune et al., 1997). However, to date, no specific information regarding the degradation of linuron and isoproturon in soil incubated under these particular conditions is available.

In contrast to the two substituted urea herbicides, flooding led to a significant decrease in the persistence of metolachlor, with half-life changing from 32.2 to 24 .1 days, under nonflooding and flooding conditions, respectively. Konopka (1994) reported the occurrence of anaerobic metabolism of metolachlor in soils. In some cases, no differences in metolachlor persistence between aerated and oxygen-limited conditions have been observed (Konopka, 1994).

Under sterilized conditions, herbicide half-lives were not influenced by water level regimes. In particular, soil sterilization caused a significant increase in persistence of the three employed herbicides with respect to nonsterile soil. No degradation of linuron, isoproturon and metolachlor was observed during the 50-day incubation period (Tab. I). The predominant role of microbial mechanisms in the overall degradation of these three herbicides has been previously reported by other authors (Fournier et al., 1975; Roberts et al., 1998; Cullington and Walker, 1999).

The opposite effect of flooding on metolachlor persistence in nonsterile soil with respect to the two substitute urea herbicides was presumably due to differences in degradation metabolisms 

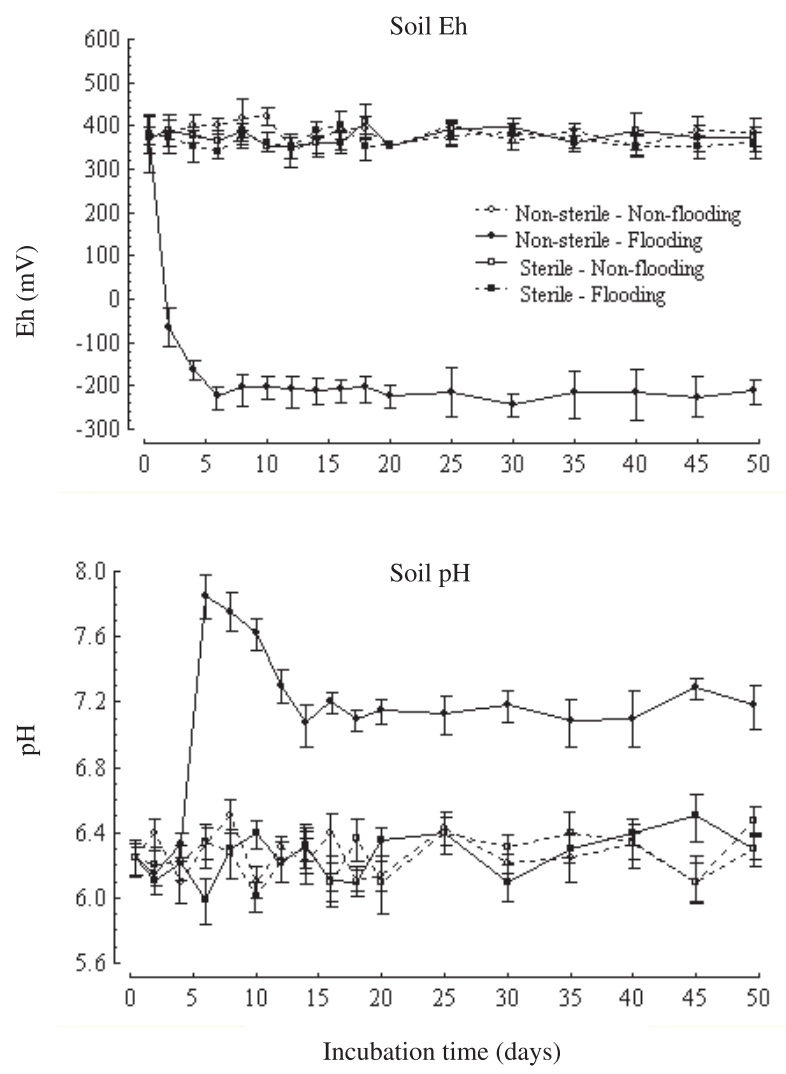

Figure 1. Dynamics of Eh (above) and $\mathrm{pH}$ (below) in nonsterile and sterile soil samples incubated under nonflooding and flooding conditions. Bars represent standard error of the mean $(n=3)$.

of these chemicals. Degradation of linuron, isoproturon and metolachlor is mainly considered a microbial process. However, while microbial degradation of metolachlor is considered a nonspecific cometabolic process (Krause et al., 1985; Saxena et al., 1987), linuron and isoproturon can be transformed into primarily growth-supporting substrates by soil microorganisms (Roberts et al., 1998; Cullington and Walker, 1999). In agreement with El-Fantroussi (2000), the latter process generally required an acclimation period to permit adaptation of soil microorganisms to the applied chemical. In addition, not all microbial communities have the ability to degrade a pesticide before the first application of that pesticide, but a further treatment is required. As described below in more detail, flooding led to a rapid and intense decrease in soil $\mathrm{Eh}$, within the first week of incubation. During the remaining incubation time, soil was characterized by strongly reducing conditions which are compatible with activity of only strict anaerobic microorganisms. The soil anaerobic microbial community would presumably have a different ability to metabolize the two substitute urea herbicides or could need a longer adaptation period to acquire this ability with respect to microbial groups growing under well-aerated conditions. However, more information is needed to support this hypothesis.

\subsection{Eh and pH}

The dynamics of Eh and $\mathrm{pH}$ changes in incubated soil samples are shown in Figure 1. Flooding led to a significant

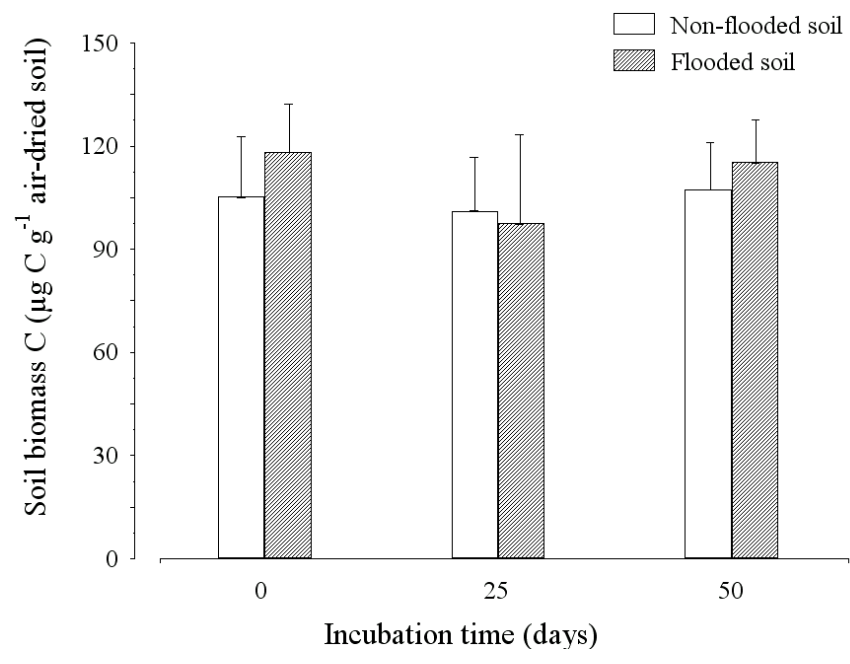

Figure 2. Soil microbial $\mathrm{C}$ of soil samples incubated under nonflooding and flooding conditions. Bars represent standard error of means $(n=3)$.

decrease in Eh in nonsterile soil samples. At the start of the experiment, Eh of flooded soil was $368.0 \mathrm{mV}$. Soil Eh rapidly dropped to $-225.5 \mathrm{mV}$ within the first week of flooding, indicating strongly reducing conditions (DeLaune and Pezeshki, 1991). After the first week, soil Eh showed small changes. Similar rapid and intense Eh decrease has been reported by other authors (DeLaune and Pezeshki, 1991; Thind and Rowell, 1999). The measured low Eh values are consistent with soils characterized by organic C content greater than $3 \%$, such as the soil employed in the present experiment, and intense microbial activity (Ponnamperuma, 1972; Wolfe and Macalady, 1991; Crawford et al., 2000). As expected, oxidizing conditions (Eh > $+350 \mathrm{mV}$ ) remained approximately stable in both nonsterile and sterile soil samples incubated at the field capacity. A similar pattern was observed with sterile flooded soil. The results suggest that the decrease in soil Eh values was caused by biological activities, as also reported by Wolfe and Macalady (1991).

Soil $\mathrm{pH}$ values of both nonsterile and sterile soil incubated under nonflooding conditions did not significantly change during the 50-day incubation period (Fig. 1). A similar pattern was observed in flooded sterile soil. In contrast, $\mathrm{pH}$ of flooded nonsterile soil showed a rapid increase, reaching a peak value of 7.9 within the first week of flooding. During the remaining incubation time, soil $\mathrm{pH}$ steadily decreased but remained significantly higher than the initial values. The increase in soil $\mathrm{pH}$ as a result of waterlogged conditions has been reported in the literature and is caused by the consumption of protons during reduction processes (Ponnamperuma, 1972; Jayaweera and Biggar, 1996; Thind and Rowell, 1999).

\subsection{Soil microbial $\mathrm{C}$}

Microbial C of flooded and nonflooded soils did not significantly change during the whole incubation period (Fig. 2). In a laboratory experiment, Accinelli et al. (2001) did not observe microbial C variation in a sandy loam soil treated with herbicides, 
within an observation period comparable with that adopted in the present study. According to Voos and Groffmann (1997), the size of the microbial biomass is a strong indicator of the pesticide degradation capacity of a soil. As described above, metolachlor showed a lower persistence in nonsterile soil samples incubated under flooding with respect to nonflooding conditions. Since soil microbial C remained approximately constant during the 50-day incubation period and considering that degradation of metolachlor is mainly a microbial process, the involvement of other degradation mechanisms cannot be excluded from occurring in nonsterile flooded samples. In contrast to oxidized conditions, where abiotic degradation of metolachlor was not observed, the involvement of an abiotic process may take on relevance under the strongly reduced conditions occurring in nonsterile flooded soil (Fig. 1). In such a strongly reducing environment, abiotic reducing reactions are believed to occur, especially in the presence of significant availability of reducing agents. Organic matter is considered to be a strong reducing agent, capable of reducing metals that can, in turn, reduce organic pollutants directly (Tratnyek and Macalady, 1989). Since the soil Eh decrease is mainly driven by biological activity, the estimation of the role of abiotic degradation in reduced sterile soil is a difficult task to achieve.

\section{CONCLUSION}

Flooding significantly influenced herbicide persistence in soil. Flooding conditions led to an increase in linuron and isoproturon persistence in soil. An opposite effect was observed with metolachlor, thus indicating that information obtained from normally aerated soils is not correctly applicable to predict herbicide half-lives under flooding conditions. Considering that, in the low-lying areas of the southeastern Po Valley and in many other agricultural sites, frequent occurrence of flooding phenomena may represent an unexpected crop cultivation interruption, knowledge of herbicide persistence under these conditions would permit a more rational decisional choice of intended crops.

\section{REFERENCES}

Accinelli C., Dinelli G., Vicari A., Catizone P. (2001) Atrazine and metolachlor degradation in subsoils, Biol. Fertil. Soils 33, 495500 .

Bohn H.L. (1968) Electromotive force of inert electrodes in soil suspensions, Soil Sci. Soc. Am. Proc. 32, 211-215.

Chung K.H., Ro K.S., Roy D. (1995) Atrazine biotransformation in wetland sediment under different nutrient conditions I: Anaerobic, J. Environ. Sci. Health A 30, 72-80.

Crawford J.J., Traina S.J., Tuovinen O.H. (2000) Bacterial degradation of atrazine in redox potential gradients in fixed-film sand columns, Soil Sci. Soc. Am. J. 64, 624-634.

Cullington J.E., Walker A. (1999) Rapid biodegradation of diuron and other phenylurea herbicides by a soil bacterium, Soil Biol. Biochem. 31, 677-686.

DeLaune R.D., Devai I., Mulbah C., Crozier C., Lindau C.W. (1997) The influence of soil redox conditions on atrazine degradation in wetlands, Agric. Ecosyst. Environ. 66, 41-46.
DeLaune R.D., Pezeshki S.R. (1991) Role of soil chemistry in vegetative ecology of wetlands, Trends Soil Sci. 1, 101-113.

Dinelli G., Accinelli C., Vicari A., Catizone P. (2000) Comparison of the persistence of atrazine and metolachlor under field and laboratory conditions, J. Agric. Food Chem. 48, 3037-3043.

El-Fantroussi S. (2000) Enrichment and molecular characterization of a bacterial culture that degrades methoxy-methyl urea herbicides and their aniline derivatives, Appl. Environ. Microbiol. 66, 51105115 .

Fournier J.C., Soulas G., Cotroux G. (1975) Dégradation microbienne de l'isoproturon dans des modèles de laboratoire, Chemosphere 4, 207-214.

Gomme J.W., Shurvell S., Hennings S.M., Clark L. (1991) Hydrology of pesticides in a chalk catchment, J. Inst. Water Environ. Manage. 5, $546-552$.

Goolsby D.A., Battaglin W.A., Thurman E.M. (1994) Occurrence and transport of agricultural chemicals in the Missisipi River during the 1993 flood, EOS Trans. Am. Geophys. Union 74, 62-71.

Jayaweera G.R., Biggar J.W. (1996) Role of redox potential in chemical transformations of selenium in soils, Soil Sci. Soc. Am. J. 60, 1056-1063.

Kelly W.R., Wilson S.D. (2000) Movement of bromide, nitrogen-15, and atrazine through flooded soils, J. Environ. Qual. 29, 10851094.

Konopka A. (1994) Anaerobic degradation of chloroacetanilide herbicides, Appl. Microbiol. Biotechnol. 42, 440-445.

Krause A., Hancock W.G., Minard R.D., Freyer A.J., Honeycutt R.C., LeBaron H.M., Paulson D.L., Liu S.Y., Bollag J.M. (1985) Microbial transformation of the herbicide metolachlor by a soil actinomycete, J. Agric. Food Chem. 33, 584-589.

Liesack W., Schnell S., Revsbech N.P. (2000) Microbiology of flooded rice paddies, FEMS Microbiol. Rev. 24, 625-645.

McFarland M.J., Beck M., Harper S., Deshmuck K. (1996) Anoxic treatment of trifluralin-contaminated soil, J. Hazard. Mater. 50, $129-141$.

McGeehan S.L., Naylor D.V. (1994) Sorption and redox transformation of arsenite and arsenate in two flooded soils, Soil. Sci. Soc. Am. J. $58,337-342$.

McKee W.H., McKelvin M.R. (1993) Geochemical processes and nutrient uptake by plants in hydric soils, Environ. Toxicol. Chem. 12, 2197-2207.

Ponnamperuma F.N. (1972) The chemistry of submerged soils, Adv. Agron. 24, 29-96.

Ponnamperuma F.N., Tianco E.M., Loy T. (1967) Redox equilibria in flooded soils: I. The iron hydroxide systems, Soil Sci. 103, 374-382.

Roberts S.J., Walker A., Cox L., Welch S.J. (1998) Isolation of isoproturon-degrading bacteria from treated soil via three different routes, J. Appl. Microbiol. 85, 309-316.

Saxena A., Zhang R., Bollag J.M. (1987) Microorganisms capable of metabolizing the herbicide metolachlor, Appl. Environ. Microbiol. 53, 390-396.

Shapir N., Mandelbaum R.T., Jacobsen C.S. (1998) Rapid atrazine mineralization under denitrifying conditions by Pseudomonas sp. Strain ADP in aquifer sediments, Environ. Sci. Technol. 32, 37893792.

Thind H.S., Rowell D.L. (1999) Effects of algae and fertilizer-nitrogen on $\mathrm{pH}$, Eh and depth of aerobic soil in laboratory columns of a flooded sandy loam, Biol. Fertil. Soils 28, 162-168. 
Tratnyek P.G., Macalady D.L. (1989) Abiotic reduction of nitro aromatic pesticides in anaerobic laboratory systems, J. Agric. Food Chem. 37, 248-254.

Vance E.D., Brookes P.C., Jenkinson D.S. (1987) An extraction method for measuring soil microbial biomass C, Soil Biol. Biochem. 19, 703-707.

Voos G., Groffmann P.M. (1997) Relationships between microbial biomass and dissipation of 2,4 D and dicamba in soil, Biol. Fertil. Soils 24, 106-111.

Walker A., Jurado-Exposito M., Bending G.D., Smith V.J.R. (2001) Spatial variability in the degradation rate of isoproturon in soil, Environ. Pollut. 111, 407-415.

Walker A., Welch S.J. (1991) Enhanced degradation of some soilapplied herbicides, Weed Res. 31, 49-57.
Walker A., Welch S.J. (1992) Further studies of the enhanced biodegradation of some soil-applied herbicides, Weed Res. 32, 19-27.

Wang F.L., Bettany J.R. (1993) Organic and inorganic nitrogen leaching from incubated soils subjected to freeze-thaw and flooding conditions, Can. J. Soil Sci. 74, 201-206.

Wolfe N.L., Macalady D.L. (1991) New perspectives in aquatic redox chemistry: Abiotic transformations of pollutants in groundwater and sediments, J. Contam. Hydrol. 9, 17-34.

Wolfe N.L., Mingelgrin U., Miller G.C. (1990) Abiotic transformations in water, sediments and soil, in: Cheng H.H. (Ed.), Pesticides in the soil environment: Processes, Impacts, and Modeling, Soil Science Society of America, pp. 103-168. 